Исайкин Дмитрий Викторович, Докторант $\mathrm{PhD}$ E-mail: dima87_i@mail.ru ORCID ID: 0000-0001-7842-1102 Майлыбаев Ерсайын Құрманбайұлы, Докторант $\mathrm{PhD}$ E-mail: ersind@mail.ru ORCID ID: 0000-0002-1977-3690 Казахский университет путей сообщения г. Алматы, Республика Казахстан

\title{
ЖЕЛЕЗНОДОРОЖНАЯ АВТОМАТИКА И ТЕЛЕМЕХАНИКА
}

\author{
Isaykin Dmitry Viktorovich, $\mathrm{PhD}$ student \\ E-mail: dima87_i@mail.ru ORCID ID: 0000-0001-7842-1102 \\ Mailybaev Yersaiyn Kurmanbayuly, $\mathrm{PhD}$ student \\ E-mail: ersind@mail.ru ORCID ID: 0000-0002-1977-3690 \\ Kazakh University Ways of Communications \\ Almaty, the Republic of Kazakhstan
}

\section{RAILWAY AUTOMATION AND TELEMECHANICS}

Annotation: This article describes the main ways to solve the problems of ensuring and regulating the safe movement of transport and a certain capacity of roads through the means and methods of telemechanical and automatic impact.

Keywords: railway automatics and telemechanics, remote control system, travel lock, stage, centralized traffic control.

Аннотация: В данной статье изложены основные способы решении задач обеспечения $и$ регулирования безопасного движения транспорта и определенной пропускной способности дорог благодаря средствам и методам телемеханического и автоматического воздействия.

Ключевые слова: железнодорожной автоматики и телемеханики, система телемеханики, путевая блокировка, перегон, диспетчерская цеентрализация.

Железнодорожная автоматика и телемеханика занимается решением задач обеспечения и регулирования безопасного движения транспорта и определенной пропускной способности дорог благодаря средствам и методам телемеханического и автоматического воздействия.

Главные составляющие технических элементов железнодорожной автоматики и телемеханики представлены сооружениями и механизмами сигнализации, централизации и блокировки. В свою очередь данные устройства и средства представлены путевой блокировкой, электрожезловой управляющей системой, централизацией стрелок и сигналов, элементами регулировки движения транспорта, диспетчерской централизацией, автоматическим диспетчерским контролированием и ограждающими установками на железнодорожных переездах.

Как правило, система автоматики занимается регулировкой, контролированием и управлением объектов в том случае, когда между ними небольшое расстояние. В случае, когда между объектами значительное расстояние, то используется система телемеханики. Железнодорожная автоматика и телемеханика делится на два класса: устройства автоматики и телемеханики на станции и перегоне.

Первая группа представлена автоматической блокировкой, локомотивной автоматической сигнализацией, путевой полуавтоматической блокировкой, системой диспетчерского контроля и автоматической переездной сигнализацией. Вторая группа представлена электрической и диспетчерской централизацией, комплексом механизмов горочной автоматики и т. д.

Железнодорожная автоматика и телемеханика
Материалы Международной практической интернет-конференции «Актуальные Проблемы Науки» 
Установки путевой блокировки - это главные технические средства, которые регулируют и обеспечивают безопасность следования составов по промежуточной станции и перегону. Термин путевая блокировка подразумевает под собой систему элементов автоматики и телемеханики, с помощью которой организовывается такое движение, при котором занятие поездом определенного отрезка дороги регулируется с применением постоянных сигналов, например, светофоров или семафоров.

Разрешение занимать поездом определенный участка железной дороги, который ограждается постоянным сигналом, определяется открытым (разрешающим) состоянием сигнала постоянного. Когда определенный отрезок дороги занят поездом, он закрывается постоянным сигналом, который получает закрытое состояние.

Во время нахождения поезда на отрезке железной дороги возможность осуществить открытие сигнала постоянного, который ограждает данный участок пути, исключается благодаря замыкающим установкам путевой блокировки. Данные элементы блокируют (электрическим и механическим способом) в закрытом состоянии постоянный сигнал до тех пор, пока не подастся информация, что поезд освободил ограждаемый отрезок дороги.

Такую информацию постоянный сигнал получает автоматически благодаря воздействию поезда на механизмы, которые контролируют проследование поезда по определенному участку пути. Таким образом, каждый огражденный отрезок дороги может иметь только один состав.

Такая автоматика и телемеханика на железнодорожном транспорте может быть полуавтоматической, когда управление происходит с участием человека, и полностью автоматической, человек не задействован. Эти устройства применяют, как при одностороннем движении, так и при двустороннем.

Электрожезловая система нашла свое применение в регулировании следования транспорта по перегонам, которые имеют двустороннее движение. Разрешение занимать перегон имеют те поезда, у которых машинист обладает жезлом данного перегона. Этот жезл машинисту выдает дежурный по станции отправления, а дежурный по станции прибытия забирает его.

Каждая станция, ограничивающая перегон, оснащена жезловыми аппаратами, которые электрически связаны между собой. Два аппарата, относящиеся к одному перегону, имеют общее число жезлов четное, как правило, от 20 до 30, при этом изъятие жезла из аппарата возможно только при четном количестве в двух аппаратах.

Дежурный по прибытию, когда получает жезл, отправляет в аппарат станции отправления электрический ток, вращая рукоятку индикатора. Таким образом, разрешает занимать поезду перегон. Жезловая система полностью исключает возможность одновременного отправления на перегон двух поездов. Линии, где движение интенсивное, оснащены автоблокировкой.

Основными техническими элементами регулирования и создания безопасного движения поездов, которые передвигаются в пределах железнодорожных станций, являются устройства централизации сигналов и стрелок. С их помощью из одного пункта (пост централизации) происходит управление сигналами и стрелками.

В зависимости от энергии, которая применяется для перевода стрелок, существует механическая централизация, в которой применяется мускульная сила человека для перевода сигналов и стрелок. Еще существует механическая централизация, в которой применяются гидравлические или электропневматические приводы. Также существует электрическая централизация с электроприводами и соответствующими схемами [1].

Железнодорожная автоматика и телемеханика
Материалы Международной практической интернет-конференции «Актуальные Проблемы Науки» 
Железнодорожная горочная автоматика и телемеханика обладает техническими элементами, способными повышать перерабатывающее умение сортировочных горок. Эти средства представлены устройствами регулировки скорости скатывания вагонов и устройствами автоматической централизации стрелок.

Существует возможность дополнения указанных средств устройствами, которые автоматически задают скорость роспуска составов, а также действуют сообща с элементами автоматического телеуправления горочным локомотивом.

Автоматическая регулировка представлена:

- устройствами, которые автоматически регулируют движение транспорта в пределах одного участка - автодиспетчер;

- устройствами, которые автоматически регулируют режимы ведения каждого поезда относительно графика следования - автомашинист;

- устройствами, которые обеспечивают автоматическое снижение скорости транспорта при его сближении с преградой - автоматика безопасности.

Вся современная автоматика безопасности взаимодействует с устройствами автоматической локомотивной сигнализации, которая автоматически в кабину управления локомотива передает информацию, соответствующую указателям путевых сигналов или относительно состояния участка дороги, лежащего впереди. Автоматическая локомотивная сигнализация в сочетании с автоматикой безопасности называется сигнальной авторегулировкой.

В диспетчерскую централизацию входят устройства электрической централизации и автоблокировка. Диспетчерская централизация управляет сигналами и стрелками раздельных пунктов железнодорожного отрезка у диспетчера поезда, а регулировка движения поездов по перегонам выполняется автоблокировкой.

Диспетчерский контроль следования поездов представлен системой, которая автоматически снабжает участкового диспетчера поезда информацией о следовании транспорта на участке, про указания светофоров и состоянии промежуточных путей станций. На диспетчерском посту установлена светосхема табло, которая и отражает место расположения поездов и состояние светофоров.

Ограждающие элементы железнодорожных переездов представляются комплексом приборов и оборудования, которые устанавливаются на участках пересечения автомобильных и железных дорог в одном уровне. Данные устройства способны автоматически управлять движущимся поездом, при этом запрещается движение автомобильного транспорта через переезд во время приближения поезда.

Автоматика и телемеханика на транспорте повышает пропускную способность железнодорожных станций и безопасность следования транспорта, а также способствует лучшему использованию подвижного состава. Автоматика телемеханика и связь дают возможность в достижении высоких показателей работы транспорта.

Относительно научно-исследовательских работ, которые направлены на дальнейшее развитие железнодорожной автоматики и телемеханики, то актуальные работы представлены в оптической сигнализации, интервальном регулировании движения транспорта. А также широко развивается область экономического эффекта от применения устройств автоматики и телемеханики в разных эксплуатационных условиях.

\section{ЛИТЕРАТУРА}

1. Оралбекова А.О. Обзор автоматизированных систем управления технологическими процессами // Промышленный транспорт Казахстана. - 2018. - №3. - С. 124-130.

Железнодорожная автоматика и телемеханика
Материалы Международной практической интернет-конференции «Актуальные Проблемы Науки» 